\title{
ESTUDIO PRELIMINAR SOBRE LA EPIFAUNA DE Hesperocidaris asteriscus (ECHINODERMATA: ECHINOIDEA)
}

\author{
por \\ Scrgio I. Salazar Vallejo \\ Laboratorio Ecología Bentos Marino \\ División Oceanología, CICESF, \\ Apartado Postal 2732, Eusenada, B. C. \\ 22800 México \\ Irma G. López Muraira \\ Laboratorio Zoología Invertebrados \\ No-Arthropoda \\ Fac. Ciencias Biológicas, UANL \\ Apartado Postal 2790, Monterrey, N.L. \\ 64000 México
}

SAlAZAR VALlEJO, S.I. e I.G. Lopez Muraira, 1983. Estudio preliminar sobre la epifauna de Hesperocidaris asteriscus Echinodermata: Echinoidea). Ciencias Marinas, 9(2):109-119.

\section{RESUMEN}

A 11 ejemplares de Hesperocidaris asteriscus colectados en el intermareal en Bahía Bocachibampo, Guaymas, Sonora, se les removieron 10 espinas por erizo. Cada espina fue examinada y los especímenes separados a taxa mayores, lucgo identificados a especie en lo posible; esto resultó en más de 20 especies de nueve Phyla animales. Las especies de mayor cobertura fueron Pseudosuberites sp., Esponja 1, Esponja 2 (Porifera), Watersipora arcuata, Cauloramphus spiniferum (Bryozoa), Salmacina tribranchiata y Janua sp. (Polychaeta). No parece existir relación entre el tamaño de $H$. asteriscus y cl número de espinas cubiertas, y el tipo de animales epifaunísticos. Previamente sólo se reportaban de la epibiosis de cste erizo, algas, esponjas y briozoos no identificados.

\begin{abstract}
From 11 specimens of Hesperocidaris asteriscus collected in Bocachibampo Bay, Guaymas, Sonora, 10 spines per animal wcre removed. Each spine was examined and the specimens were sorted out to major taxa, then identified whenever possible to species; this resulted in more than 20 species of nine animal Phyla. The species with biggest cover were Pseudosuberites sp., Sponge 1, Sponge 2 (Porifera), Watersipora arcuata, Caulorampus spiniferum (Bryozoa), Salmacina tribranchiata, and Janua sp. (Polychaeta). There seems to be no relation between H. asteriscus size and the number of spincs covered, and the kind of its fouling animals. Unidentified algae, bryozoans and sponges had been previously reported as this sea-urchin foulers.
\end{abstract}

\section{INTRODUCCION}

Los equinoideos juegan un relevante papel en las relaciones tróficas de muchas comunidades marinas. La alimentación por raspado de estos animales puede alterar la distribución y la abundancia relativa de las plantas marinas tales como macroalgas (Breen \& Mann, 1976; Sammarco, 1982b) o de pastos marinos (Ogden et al., 1973) lo que puede afectar indirectamente a las poblaciones animales. Otros equinoides pueden alterar directamente la colonización y la recolonización de corales (Dart, 1972), alterar la composición de la epifauna coralina (Sammarco et al., 1974), o controlar las comunidades coralinas (Sammarco, 1982a). La especie Hesperocidaris asteriscus limita el 
crecimiento de los arrecifes coralinos en las Islas Galápagos, pero no en los de aguas continentales, debido tal vez a que sus predadores son menos abundantes en el archipiélago (Glynn et al., 1979).

$H$. asteriscus es uno de los erizos regulares más comunes en la costa tropical del Pacífico de América; ocurre sobre rocas y arrecifes en las zonas meso- e infralitoral, expuestas al oleaje, pero puede llegar hasta los $150 \mathrm{~m}$ de profundidad. Su diámetro testal alcanza $70 \mathrm{~mm}$ y posee de 50 a 80 espinas primarias dispuestas en 10 hileras verticales de 5 a 8 espinas cada una; las espinas son pardas, cónicas, largas y romas. Brusca (1980) confunde esta especie con Eucidaris thouarsii, pero ambas se distinguen fácilmente (Ver Caso, 1978). En la Bahía de la Paz, Baja California Sur, estos animales se alimentan casi totalmente de coral (Brand, 1979) y son probablemente controlados por los peces Bodianus taenia, Sufflamen verres y Arothron meleagris, mismos que los controlan en Ecuador (Glynn et al., 1979) y que se distribuyen por toda la costa tropical del Pacífico de América (Thomson et al., 1979).

Las espinas de los cidaroides están cubiertas con epidermis ciliada que desaparece cuando se diferencia la corteza, la cual es una capa extra, delgada y sólida que porta ornamentaciones y proyecciones piliformes (Hyman, 1955). La epidermis desaparece en los individuos maduros de Eucidaris tribuloides, permitiendo así la captación de detritos y la fijación de algunos organismos que constituyen la cpibiosis (McPherson, 1968).

Los organismos reportados sobre las espinas de $H$. asteriscus no han sido identificados hasta especie; se sabe que incluyen colonias blancas de briozoos (Steinbeck \& Ricketts, 1941), csponjas y algas calcáreas (Brusca 1973, 1980).

En este trabajo formulamos una lista preliminar sobre la epifauna de $H$. asteriscus, y analizamos la relación entre el tamaño del erizo y el número de espinas cubiertas y el tipo de organismos presentes.

\section{MATERIAL Y METOODOS}

El Biol. M. Villarreal (UANL) colectó 11 ejemplares de $H$. asteriscus en el intermareal de la Bahía de Bocachibampo, Guaymas, Sonora, el 7 de abril de 1977. Los fijó en una solución de formalina al $10 \%$ en agua de mar y permanecieron los ejemplares en el fijador por cuatro años. Esto permitió que las estructuras calcáreas se disolvieran parcialmente y aumentara su fragilidad.

Medimos los erizos según McPherson (1968), y los analizamos según su talla. A cada erizo se les desprendieron 10 espinas primarias, cada una de ellas fue analizada, y los epibiontes separados a taxa mayores y posteriormente, fueron identificados hasta especie.

Para determinar el número de espinas cubiertas por cada especie epibiótica, consideramos todas las espinas remanentes en el animal, y contamos sólo aquellas que estaban cubiertas por algún organismo en por lo menos el $50 \%$ de la superficie total de la espina. También observamos la aparente preferencia de los epibiontes por las espinas peristómicas o periproctales, y de su posición a lo largo de la espina.

\section{RESULTADOS}

La epifauna de Hesperocidaris asteriscus está constituida por más de 20 especies; los taxa con mayor número de especies son Polychaeta con nueve especies, Bryozoa con cinco especies y Bivalvia con tres especies (Tabla 1). Algunas no muestran preferencia en cuanto a su posición a lo largo de la espina, como los poliquetos Salmacina tribranchiata, y Janua (Pillaiospira) sp., o las especies de briozoos. Sin embargo, otras, como el ostión Ostrea palmula y el cirripedio Balanus trigonus, se localizan solamente en la punta o hacia la punta de algunas espinas periproctales.

Sólo una de las especies, el poliqueto Polydora ca. armata, perfora las espinas del erizo, las restantes especies de organismos perforadores, como el poliqueto Dodecaceria sp. y los bivalvos Lithophaga aristata y $L$. spatiosa, horadan entre los tubos de serpúlidos y espirórbidos. Los briozoos han sido 
Salazar-López

TABLA 1. Lista de las especies de la Epifauna de Hesperocidaris asteriscus.

\section{PROTOZOA}

Foraminifera

Quinqueloculina sp.

\section{PORIFERA}

Pseudosuberites sp.

Esponja 1

Esponja 2

\section{CNIDARIA}

Hidrozoa NI

\section{NEMATODA NI}

\section{BRIOZOA}

Alderina smmiti

Cauloramohus spiniferum

Floridina antiqua

Hippopodinella adpressa

Watersipora arcuata

\section{MOLLUSCA}

Bivalvia

Lithophaga aristata

Lithophaga spatiosa

Ostrea palmula

\section{ANNELIDA}

Polychaeta

Dodecaceria sp.

Genetyllis sp.

Hydroides crucigera

Janua (Pillaiospira) sp.

Parasphaerosyllis sp.

Polydora ca. armata

Salmacina tribranchiata

Syllis gracilis

Typosyllis aciculata

\section{CRUST ACEA}

Amphipoda NI

Cirripedia

Balanus trigonus

Isopoda NI

\section{ECHINODERMATA}

Ophiuroidea

Ophiactis sp.

NI: No identificados

tratados en detalle por López-Muraira (1982). Los poliquetos Dodecaceria sp., Genetillys, sp., Janua (Pillaiospira) sp. y Parasphaerosyllis sp. parecen ser especies no descritas; junto con el resto de poliquetos se tratarán en detalle posteriormente.

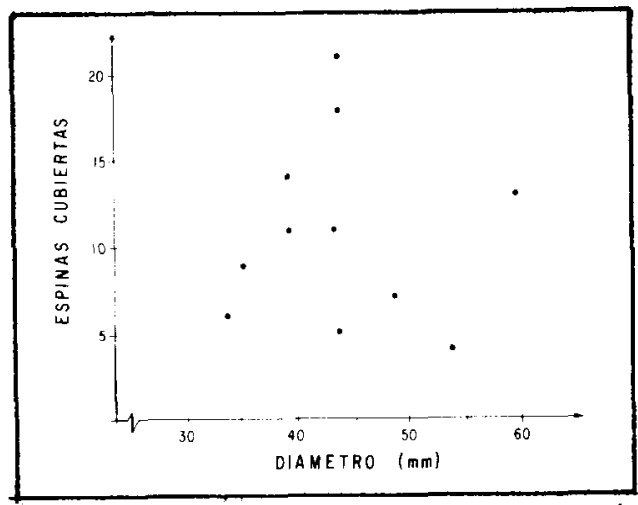

FIGURA 1. Relación entre tamaño del erizo y número de espinas cubiertas.
La relación entre tamaño del erizo y número de espinas cubiertas se muestra en la figura 1. No parece existir relación entre el tamaño del erizo y el número de espinas cubiertas ya que en general, los erizos de tamaño intermedio presentan mayores números de espinas con una cobertura mayor o igual al $50 \%$, que los ejemplares más grandes.

Por lo que respecta a la abundancia de espinas cubiertas por algún grupo o especie, encontramos que tal abundancia no es constante (Tabla 2), ni en los analizados por especie ni en los analizados colectivamente. Sólo las esponjas se presentan en todos los ejemplares, pero no se percibe una tendencia en las abundancias rclarivas de cada grupo (Figura 2).

Las espinas periproctales son comúnmente mayores; estaban generalmente cubiertas, en parte por lo menos. Las peristó- 
TABLA 2. Tamaño del ejemplar de Hesperocidaris asteriscus y número de espinas cubiertas ${ }^{1}$ por los distintos taxa.

\begin{tabular}{|c|c|c|c|c|c|c|c|}
\hline \multirow[b]{2}{*}{ Erizo } & \multicolumn{2}{|c|}{ TESTA $(\mathrm{mm})$} & \multirow[t]{2}{*}{ PORIFERA 2} & \multirow{2}{*}{ BRYOZOA } & \multicolumn{2}{|c|}{ POLYCHAETA } & \multirow{2}{*}{ SUMA } \\
\hline & Diámetro & Altura & & & S. tribranchiata & Janua sp. & \\
\hline 1 & 33.5 & 20 & 1 & 2 & 1 & 2 & 6 \\
\hline 2 & 35.5 & 23 & 3 & - & 6 & - & 9 \\
\hline 3 & 40 & 23.5 & 7 & 2 & - & 5 & 14 \\
\hline 4 & 40.5 & 23 & 6 & - & 1 & 4 & 11 \\
\hline 5 & 44 & 27 & 1 & - & 4 & - & 5 \\
\hline 6 & 44 & 27.5 & 4 & $3^{*}$ & 9 & 5 & 21 \\
\hline 7 & 43.5 & 29 & 2 & 3 & - & 6 & 11 \\
\hline 8 & 44 & 27.5 & 8 & 2 & 7 & 1 & 18 \\
\hline 9 & 49 & 29.5 & 4 & - & 2 & 1 & 7 \\
\hline 10 & 53.5 & 33 & 2 & - & 1 & 1 & 4 \\
\hline 11 & 60 & 36 & 5 & - & - & 8 & 13 \\
\hline & TOTALES & & 43 & 12 & 31 & 33 & 119 \\
\hline
\end{tabular}

1 Por lo menos el 50 o/o de su superficie

2 Las tres especies consideradas colectivamente

* Estas tres pertenecen a Cauloramphus spiniferum, las demás a Watersipora arcuata

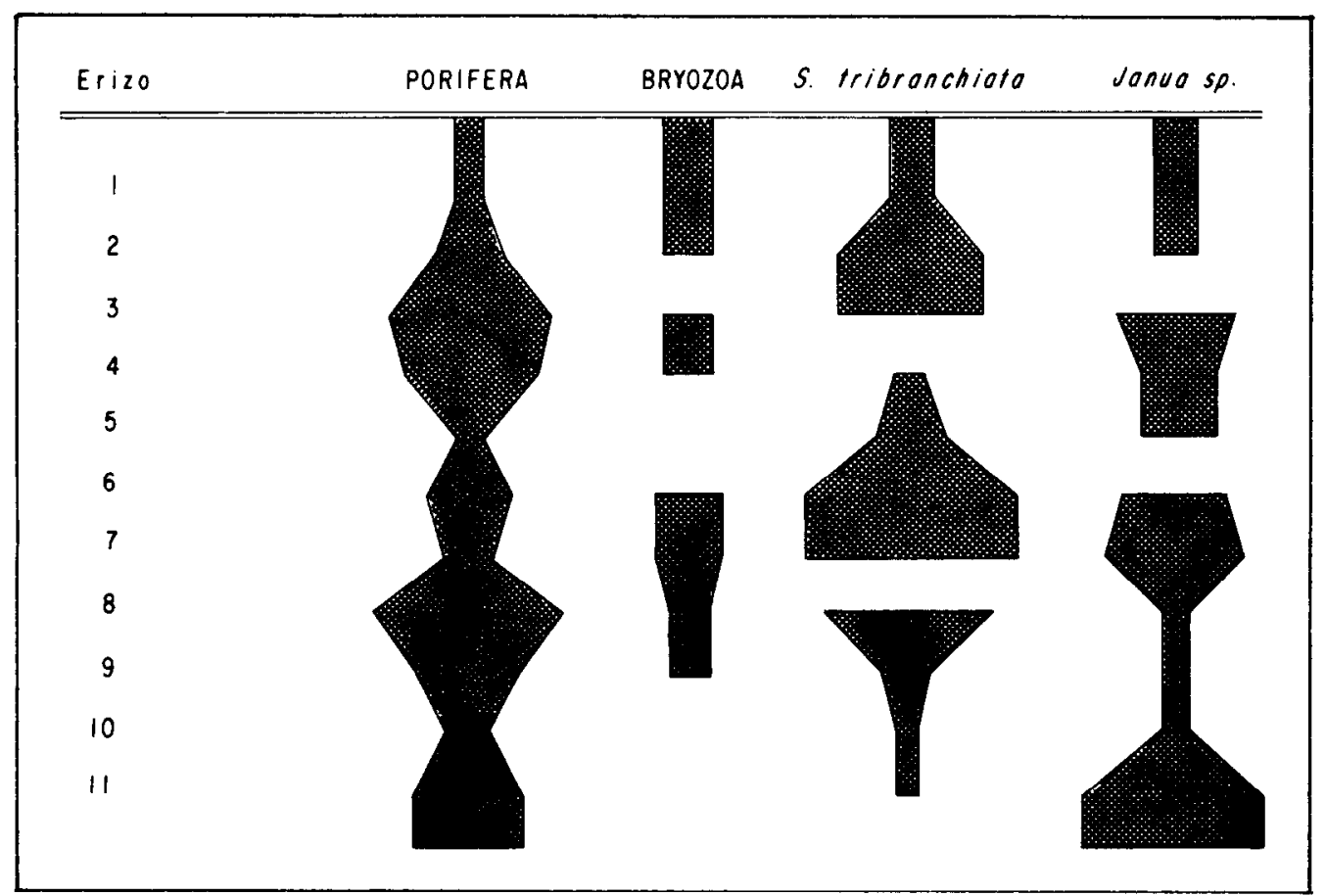

FIGURA 2. Abundancia relativa de las especies de mayor cobertura de las espinas de Hesperocidaris asteriscus (datos de la Tabla 2). 
micas son bastante menores, y no poseían ningún apibionte, pero no cuantificamos esta observación.

\section{DISCUSION Y CONCLUSIONES}

La mayoría de las especies de la epifauna de $H$. asteriscus había sido reportada antes de otro tipo de sustrato calcáreo, ya sean conchas o piedras calizas (Blake \& Evans, 1973, Houston, 1980; Hartman, 1969). Sin embargo, esta es la primera ver. que se reportan de la epifauna de un equinodermo.

Como hemos mostrado, no parece existir relación entre el tamaño del erizo y el número de espinas cubiertas. Cabría esperar que como los incrementos en la talla representan mayor edad, y más tiempo de exposición de las espinas, entonces los erizos mayores deberían mostrar etapas tardías en la sucesión sobre el sustrato y etapas tempranas en los erizos menores, pero no fue así.

Las espinas periproctales parecían estar generalmente cubiertas, por lo menos en parte, en contraste con las peristómicas. Esto es también evidente en ejemplares de esta especie colectados en la Bahía de la Paz (Brand, com.pers.). No parece haber razón de que así ocurra si se considera que al alimentarse el erizo, desprende partículas que podrían emplearse como fuente de alimento por algún suspensívoro, mientras que en la región periproctal, deben existir grandes concentraciones de hidróxido de amonio. Sin embargo, estos animales viven generalmente expuestos al oleaje; entonces, el problema de contaminación por heces del erizo es mínimo. Por otro lado, el factor limitante de las espinas peristómicas, aún a pesar del alimento disponible, es la erosión. El animal emplea, junto con la linterna de Aristóteles, las espinas peristómicas tanto para la excavación como para fijarse en las depresiones que agranda en la roca. Por lo tanto, la superficie de las espinas peristómicas debe estar sujeta a una enorme abrasión y esto explica su desnudez.

En cuanto a las especies que se limitan a las áreas distales o subdistales de las espinas, tales como Balanus trigonus y Ostrea palmula, su presencia en esas áreas podría obedecer a que las larvas seleccionan el sustrato más liso, o que "seleccionen" las condiciones de corrientes óptimas para su desarrollo.

Por último, agregamos que resta mucho por hacer en el estudio de la cpibiosis de Hesperocidaris asteriscus, y que estudios posteriores proporcionarán información sobre cuestiones referentes a la sucesión en las comunidades marinas, ya que a diferencia de otros sustratos estudiados, artificial (Sutherland \& Karlson,1977) o casi natural (Osman, 1977), las espinas de los erizos son enteramente naturales, y los ejemplares pueden manipularse fácilmente. Tales estudios, podrían mostrarnos que la asociación de la epibiosis mencionada es una comunidad muy especial.

\section{AGRADECIMIENTOS}

Agradecemos al Biól. M. Villarreal (UANL) por habernos porporcionado los erizos; a las administraciones del CICESE y de la UANL (Fac. Ciencias Biológicas) por el apoyo brindado para realizar este estudio. El Dr. Tim Brand revisó el borrador; él y algunos revisores anónimos contribuyeron a mejorar esta forma final. Dolores Peralta mecanografió el escrito y Sergio Ramos hizo las ilustraciones.

El primer autor es becario del CONACYT en CICESE.

\section{LITERATURA CITADA}

BLAKE, J. A. and J. W. Evans, 1973. Polydora and related genera as borers in mollusk shells and other calcareous substrates. Veliger, (3): $235-249$.

BRAND, T. 1979. Relaciones tróficas de cinco especies de erizos en la Bahía de la Paz, Baja California Sur. Simp. Biol. Mar. Cal. Baja Cal., 2. 10 pp.

BREEN, P. A. and K. H. Mann, 1976. Destructive grazing of Kelp by Sea Urchin in Eastern Canada . J. Fish. Res. Bd. Canada, 33(6): 1278-1283. 
BRUSCA, R. C. 1973. A Handbook to the Common Intertidal Invertebrates of the Gulf of California. Univ. Arizona Press, xvii $-427 \mathrm{pp}$.

1980. Common Intertidal Invertebrates of the Gulf of California. 2nd. Ed. Ibid, $\mathrm{xx}-513 \mathrm{pp}$.

CASO, M. E. 1978. Los equinoideos del Pacífico de México, I. Ordenes Cidaroidea y Aulodonto; II. Ordenes Stiridonta y Camaradonta. Centro Cienc. Mar. Limnol. (UNAM), Publ. Esp., 1:1-244.

DART, J. K. G. 1972. Echinoids, algal lawn and coral recolonization. Nature, 239:50-51.

GLYNN, P. W., G. M. Wellington and C. Birkeland, 1979. Coral reef growth in the Galápagos: Limitation by Sea Urchins. Science, 203:47-49

HARTMAN, O. 1969. Atlas of the Sedentariate Polychaetous Annelids from California. Allan Hancock Found., Univ. So. Cal., $812 \mathrm{pp}$.

HOUSTON, R. S. 1980 . Mollusca. In:Common Intertidal Invertebrates of the Gulf of $\mathrm{Ca}$ lifornia. 2nd. Ed. Univ. Arizona Press, 130-204.

HYMAN, L. H. 1955. The Invertebrates, IV. Echinodermata, The Coelomate Bilateria. McGraw-Hill, viii - 763 pp.

LOPEZ-MURAIRA, I. G. 1982. La Colección de Ectoprocta (Bryozoa) de la Facultad de Ciencias Biológicas de la U. A. N. L. Tes. Prof., Fac. Cienc. Biol., UANL, vi -58 pp.

McPHERSON, B. F. 1968. Contribution to the Biology of the Sea Urchin Eucidaris tribuloides (Lamarck). Bull. Mar. Sci., 18 (2):400-443.
OGDEN, J. C., R. A. Brown and N. Salesky, 1973. Grazing by the echinoid Diademe antillarum Philippi: Formation of halos around West Indian Patch Reefs. Science, 182: 715-717.

OSMAN, R. W. 1977. The establishment and development of a marine epifaunal community. Ecol. Monogr., 47:37-63.

SAMMARCO, P. W. 1982a, Echinoid grazing as a structuring force in Coral Communities: Whole reef manipulations. J. Exp. Mar. Biol. Ecol., 61(1): 31-56.

1982b. Effects of grazing by Diadema antillarum Philippe (Echinodermata: Echinoidea) on Alfal Diversity and Community Structure. Ibid., 65:83-105.

SAMMARCO, P.W., J.S. Levinton \& J.C. Ogden, 1974. Grazing and Control of Coral Reef Community Structury by Diadema antillarum Philippi (Echinodermata:Echinoidea): A Preliminary Study. J. Mar. Res., 32: 47-53.

SUTHERLAND, J.P. and R. H. Karlson, 1977. Development and stability of the Fouling community at Beaufort, North Carolina. Ecol. Monogr., 47: 426-446.

STEINBECK, J. and E.F. Ricketts, 1941. Sea of Cortes, a Leisurely Journal of Travel and Research. Viking Press, $598 \mathrm{pp}$.

THOMSON, D.A.; L.T. Findley and A. N. Kerstitch, 1979. Reef Fishes of the Sea of Cortes, the Rocky Shore Fishes of the Gulf of California. John Wiley and sons, $\mathrm{xvii}-302 \mathrm{pp}$. 


\title{
PRELIMINARY STUDY ON THE EPIFAUNA OF Hesperocidaris asteriscus (ECHINODERMATA: ECHINOIDEA)
}

\author{
by \\ Sergio 1. Salazar Vallejo \\ Laboratorio Ecología Bentos Marino \\ División Oceanología, CICESE \\ Apartado Postal 2732, Ensenada, B.C. \\ 22800 México \\ Irma G. López Muraira \\ Laboratorio Zoología Invertebrados \\ No-Arthropoda \\ Fac. Ciencias Biológicas, UANL \\ Apartado Postal 2790, Monterrey, N.L. \\ 64000 México
}

SALAZAR-VALLEJO, S.I. and I.G. Lopez Muraira, 1983. Preliminary study on the epifauna of Hesperocidaris asteriscus (Echinodermata: Echinoidea). Ciencias Marinas, 9(2): 109-119.

\section{INTRODUCTION.}

The echinoids play an important role in the trophic relations of many marine communities. The feeding of these organisms may alter the distribution and relative abundance of marine plants such as macro algae (Breen Mann, 1976; Sammarco, 1982b) or seaweeds (Ogden et al., 1973) which may indirectly affect animal populations. Other echinoids may directly alter the colonization and recolonization of corals (Dart, 1972), the composition of the coraline epifauna (Samarco et al al., 1974), or regulate the coraline communities (Sammarco et al., 1982a). The species Hesperocidaris asteriscus limits coral reef growth in the Galapagos Islands, but it fails to do so in continental waters, perhaps due to the fact that its predators are less abundant in the archipelago (Glynn et al., 1979).

H. asteriscus is onc of the most common echinoids on the tropical pacific coast of America; it occurs on rocks and reefs in the mese - and infralittoral zones, exposed to wave action, although it may be collected at depths to $150 \mathrm{~m}$. Its testal diameter may reach $70 \mathrm{~mm}$ and has 50 to 80 primary spines arranged in 10 vertical rows, each with 5 to 8 spines. The spines are long and blunt. Brusca (1980) confuses this species with Eucidaris thouarsii, but both are easily distinguishable (See Caso, 1978). In La Paz bay,
Baja California Sur, these animals feed almost exclusively on coral (Brand, 1979) and are probably regulated by the fishes $B$ odianus taenia, Sufflamen verres, and Arothron meleagris, the same ones which regulate them in Ecuador (Glynn et al., 1979) and whose distribution spans through the tropical coast of the Pacific Ocean in America (Thomson et al., 1979).

The primary spines of the cidaroids are covered with a ciliated epidermis which disappears when the cortex becomes differentiated. It is a thin and solid extra layer, which bears ornamentations and hair-like projections (Hyman, 1955). The epidermis disappears in mature specimens of Eucidaris tribuloides, cnabling the detritus captation and settlement of several organisms which make up the epibiosis (McPherson, 1968).

The organisms reported as foulers on the spines of $H$. asteriscus have never been identified to species; although it is known that they include white bryozoans colonies (Steinbeck \& Ricketts 1941), sponges and calcareous algae (Brusca, 1973, 1980).

In this paper, we make a preliminary list on $H$. asteriscus foulers, and analize the relation between sea urchin size, number of 
spines covered, and the kind of organisms present.

\section{MATERIAL AND METHODS.}

Eleven specimens of $H$. asteriscus were collected by Biol. M. Villarreal (UANL) in the intertidal zone of the Bahía de Bocachibampo, Guaymas, sonora, on April 7, 1977. They were fixed with a $10 \mathrm{o} / \mathrm{o}$ formalin marine water solution, and the specimens remained in the fixative for four years. This partly dissolved the calcareous structures and increased its fragility.

We measured the sea urchins following McPherson (1968), and analyzed them in agreement with their size. Ten primary spines per sea urchin were removed, each one was analyzed, and the foulers were sorted out to major taxa, and later identified to spccics.
In order to determine the number of spines covered by each fouler, we observed all the remaining spines on the animal, and counted them only if they were covered by any fouler on at least 50 o/o of the total spine surface. We also observed the apparent preference of the foulers by the peristomic or periproctal spines, and of their position along the spine.

\section{RESULTS.}

Hesperocidaris asteriscus has a fouling association of over 20 species; the taxa with highest number of species are Polychaeta with nine especies, Bryozoa with five species an Bivalvia with three species (Table 1 ). Some species did not show any preference regarding its position along the spine, such as the polychaetes Salmacina tribranchiata and Janua (Phillaiospira) sp., or the bryozoan species. However, other species, such as

TABLE 1. Species of the epifauna on Hesperocidaris asteriscus.

PROTOZOA

Foraminifera

Quinqueloculina sp.

\section{PORIFERA}

Pseudosuberites sp.

Esponja 1

Esponja 2

\section{CNIDARIA}

Hidrozoa NI

\section{NEMATODA NI}

BRIOZOA

Alderina smmiti

Caulorambhus spiniferum

Floridina antiqua

Hippopodinella adpressa

Watersipora arcuata

\section{MOLLUSCA}

Bivalvia

Lithophaga aristata

Lithophaga spatiosa

Ostrea palmula
ANNELIDA

Polychaeta

Dodecaceria sp.

Genetyllis sp.

Hydroides crucigera

Janua (Pillaiospira) sp.

Parasphaerosyllis sp.

Polydora ca. armata

Salmacina tribranchiata

Syllis gracilis

Typosyllis aciculata

\section{CRUSTACEA}

Amphipoda NI

Cirripedia

Balanus trigonus

Isopoda NI

\section{ECHINODERMATA}

Ophiuroidea

Ophiactis sp.

NI: No identificados 
the oyster Ostrea palmula and the barnacle Balanus trigonus, are only localized on the tip or towards the tip of some periproctal spines.

Only one of the species, the polychaete Polydora ca armata, bores the sea urchin spines, the remaining borer species, such as the polychaete Dodecaceria sp. and the bivalves Lithophaga aristata and L. spatiosa, bore among the serpulid and spirorbid tubes. The bryozoans have been treated in detail by Lopez-Muraira (1982). The polychaetes Dodecaceria sp., Genetyllis sp., Janua (Phillaiospira) sp. and Parasphaerosyllis sp. seem to be undescribed species; together with the remaining polychaetes will be reported in a future paper.

The relation between the echinoid size and the number of spines covered is shown in the figure 1. There scems to be no relation between the above variables because in general, the intermediate size echinoids showed higher number of spines with a cover greater than or equal to $50 \mathrm{o} / \mathrm{o}$ than the larger specimens.

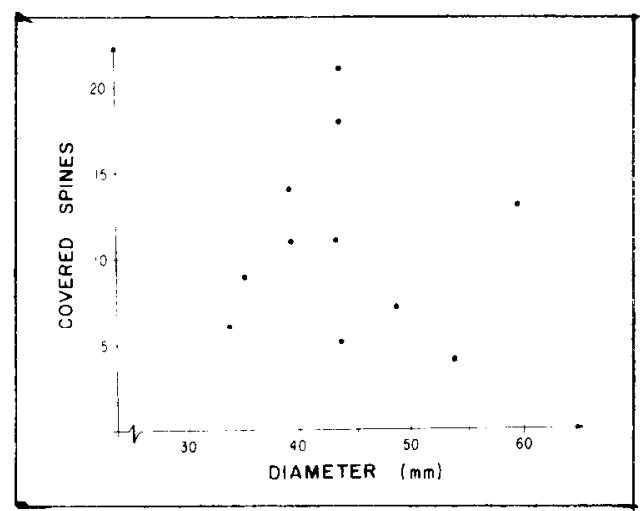

FIGIRF 1. Relationship between the urchin's size and the number of covered spines.

The abundance of spines covered by any animal group or species is not constant (Table 2), neither in the ones analyzed by species nor in the ones analyzed colectively. Only the sponges were present on every specimen, but there is not a tendency in the relative abundances of each group (Figure 2).

The periproctal spines are commonly larger than the peristomic, and were usually covered at least in part. The peristomic spines are distinctly shorter, and have no fouler on them, but we failed to quantify this observation.

\section{DISCUSSION AND CONCLUSIONS}

Most species of the fouling association of $H$. asteriscus have been reported earlier from other kinds of calcareous substrates; either shells or limestones (Blake \& Evans, 1973; Houston, 1980; Hartman, 1969). However, this is the first time that they are reported as foulers of sea urchin spines.

As we have shown, there is not an apparent relationship bctwcen the echinoid size and the number of spines covered. If we could expect that increase size means an older age, and therefore more exposition time of the spines, then the larger echinoids should have later succesional stages on the substrate, and early stages on the younger echinoids, however this was not found.

The periproctal spines secmed to usually be covered at least in part, in contrast with the peristomic spines. This was also observed in other specimens of this species collected in La Paz Bay (Brand, pers. comm.). This seems to be unexplainable if we consider that the feeding activity of the echinoid releases particles which could be used as a source of energy for some suspension feeders while in the periproctal region, there should be high concentrations of ammonia. However, because these animals usually live exposed to wave action the problem of fecal pollution becomes minimal. On the other hand, the limiting factor of the peristomic spines,even if we consider the available food, is erosion. The echinoid uses, along with the Aristotle lantern, the peristomic spines both to excavate and to fix itself in the depresions which it enlarges on rocks. Therefore, the peristomic spine's surface must be exposed to an enormous amount of friction thus explaining its bareness.

As for the species limited to the distal or subdistal areas of the spines, such as Balanus trigonus and Ostrea palmula, their 
TABLE II. The size of Hesperocidaris asteriscus specimens and the number of covercd spines by different taxa.

\begin{tabular}{|c|c|c|c|c|c|c|c|c|}
\hline \multirow[b]{2}{*}{ Urchin } & \multicolumn{2}{|c|}{$\mathrm{TEST}(\mathrm{mm})$} & \multirow{2}{*}{\multicolumn{2}{|c|}{ PORIFERA 2}} & BRYOZOA & \multicolumn{2}{|c|}{ POLYCHAETA } & \multirow{2}{*}{ SUMA } \\
\hline & Diameter & Height & & & & chiato & Janua sp. & \\
\hline 1 & 33.5 & & 20 & 1 & 2 & 1 & 2 & 6 \\
\hline 2 & 35.5 & & 23 & 3 & - & 6 & - & 9 \\
\hline 3 & 40 & & 23.5 & 7 & 2 & - & 5 & 14 \\
\hline 4 & 40.5 & & 23 & 6 & - & 1 & 4 & 11 \\
\hline 5 & 44 & & 27 & 1 & -- & 4 & - & 5 \\
\hline 6 & 44 & & 27.5 & 4 & $3^{*}$ & 9 & 5 & 21 \\
\hline 7 & 43.5 & & 29 & 2 & 3 & - & 6 & 11 \\
\hline 8 & 44 & & 27.5 & 8 & 2 & 7 & 1 & 18 \\
\hline 9 & 49 & & 29.5 & 4 & - & 2 & 1 & 7 \\
\hline 10 & 53.5 & & 33 & 2 & - & 1 & 1 & 4 \\
\hline 11 & 60 & & 36 & 5 & - & - & 8 & 13 \\
\hline & Totals & & & 43 & 12 & 31 & 33 & 119 \\
\hline
\end{tabular}

1 At least $50 \%$ of covered surface

2 The three species colectively considered

* These threee belong to Cauloramphus spiniferum, the rest to Watersipora arcuata

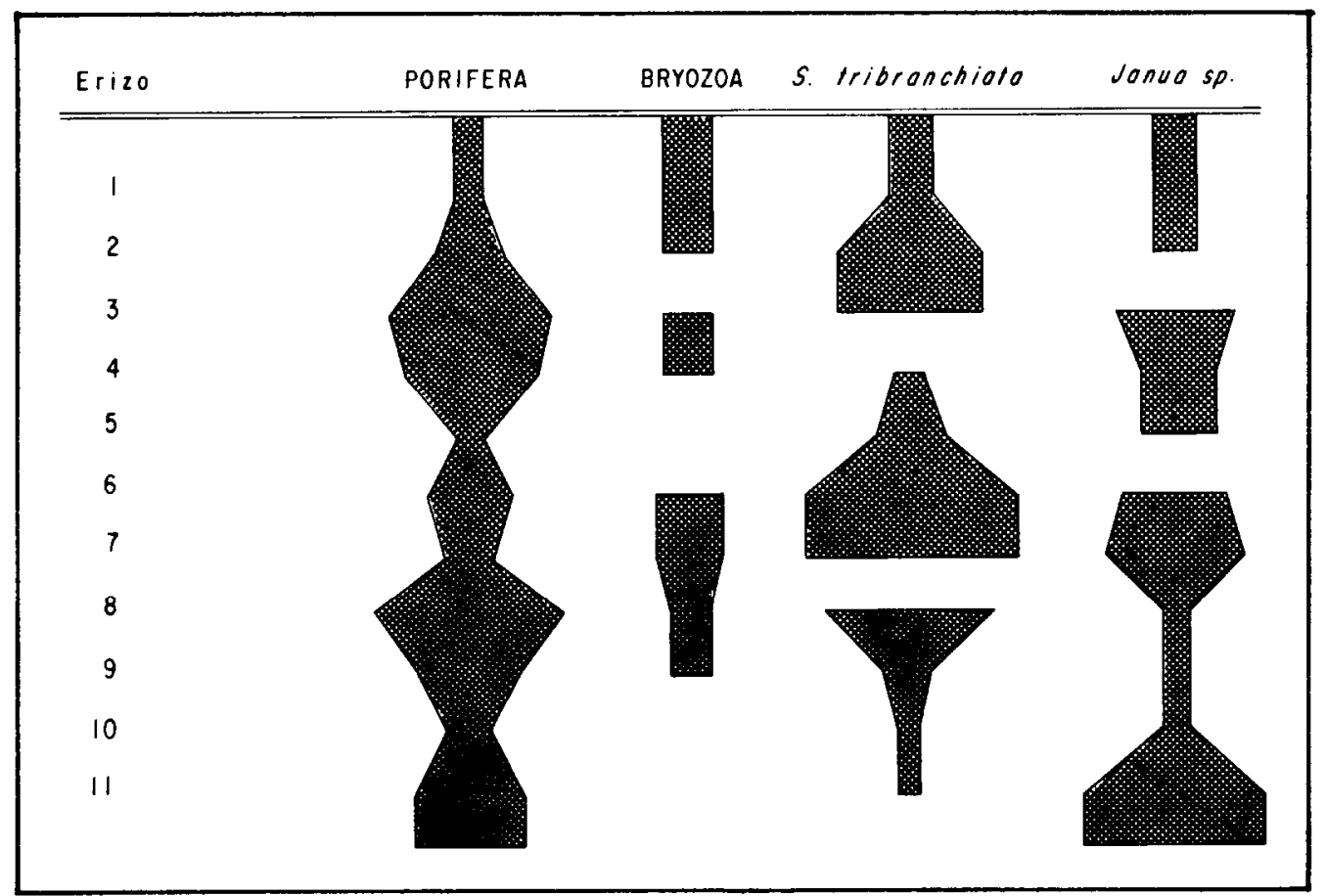

FIGURE 2. Relative abundance of the species with greater coberture on the spines of Hesperocidaris asteriscus. 
presence on these areas could reflect the fact that larvae choose the less rugose substrate, or that they "select" the optimal current conditions for their development.

Finally, it could be added that there remains a lot to be done in the study of the foulers of Hesperocidaris asteriscus, and that further studies will give information on the questions related to the succesion in the marine communities, because unlike other studied substrates, either artificial (Sutherland \& Karlson, 1977) or cuasi-natural (Osman, 1977), the echinoid spines are natural and the specimens may be handled easily.
Such studies, could show us that the fouling association is a very special community.

\section{ACKNOWLEDGEMENTS.}

We would like to thank Biol. M. Villarreal (UANL) for having provided the echinoids; to the CICESE and UANL (Fac. Ciencias Biológicas) for the facilities provided for this study. Dr. Tim Brand reviewed an early manuscript; he and some anonymous reviewers contributed to improve this final form. Dolores Peralta typewrited this paper and Sergio Ramos made the illustrations. The first author is a research assistant from CONACYT in CICESE. 